Yüzüncü Y1 Üniversitesi
Tarim Bilimleri Dergisi

Araştırma Makalesi (Research Article)

The Effects of Hungarian Vetch (Vicia pannonica Crantz.) and Triticale ( $x$ Triticosecale sp. Wittmack) Sown in Different Seed Rates on Feed Value and Ruminal Degradability Characteristics of Nutrients

\author{
Numan KILIÇALP ${ }^{* 1}$, Mahir ÖZKURT ${ }^{2}$, Yaşar KARADAĞ $\breve{G}^{3}$ \\ ${ }^{1}$ Department of Animal Science, Agricultural Faculty, Gaziosmanpaşa University, 60240 Taşlıçiftlik/Tokat, \\ Turkey \\ ${ }^{2,3}$ Depertmant of Crop Science, Faculty of Applied Sciences, Muş Alparslan University Complex, 49250, \\ Muş/Turkey \\ ${ }^{1}$ https://orcid.org/0000-0002-1431-6810 2https://orcid.org/0000-0003-0058-3026 3 https://orcid.org/0000-0002- 0523-9470 \\ *Corresponding author e-mail: numankilicalp@hotmail.com
}

\section{Article Info}

Received: 11.03.2020

Accepted: 07.08.2020

Online Published 30.09.2020

DOI: $10.29133 /$ yyutbd.702354

Keywords

Hay yield, Hungarian vetch,

Nutritive value,

Ruminal degradability,

Triticale.
Abstract: The aim of the study was to determine forage yield, forage quality and in situ rumen degradation characteristics of Hungarian vetch (Vicia pannonica Crantz.) mixtures with triticale (x Triticosecale sp. Wittmack) in different seeding rates (HV, 75:25 HVT, 50:50 HVT, 25:75 HVT and T) during the flowering period of triticale. The research was carried out in the experimental lands of Gaziosmanpaşa University Agricultural Application and Research Center during the 2015-2016 vegetation period. Field experiment was designed as Randomized Block Design with 3 replicates. Besides, three rumen cannulated Karayaka rams (average 3 year old) were used to determine dry matter degradablity characteristics of pure and mixtures by using in situ method according to randomized design. The results that biomass and dry matter yield were not different among the groups, whereas the highest crude protein concentration (13.12\%) was determined in the pure sown Hungarian vetch $(\mathrm{P}<0.01)$. In addition, the maximum crude protein yield was obtained from 75:25HVT group. In terms of effective dry matter digestibility, 50:50HVT experimental group, ED2, ED5 and ED8 (720.82, 706.1 and $692.64 \mathrm{~g} \mathrm{~kg}^{-1}$ ) was found to have the highest dry matter degradability. It was concluded that in case of mixed cultivation of Hungarian vetch and triticale, more digestible dry matter yield and crude protein yield can be obtained compared to pure cultivation.

\title{
Farklı Tohum Oranlarında Ekilen Macar Fiği (Vicia Pannonica Crantz.) ve Tritikalenin (Xtriticosecale Wittmack) Yem Değeri ve Rumende Parçalanabilirlik Özellikleri Üzerine Etkileri
}

\section{Makale Bilgileri}

Geliş: 11.03 .2020

Kabul: 07.08.2020

Online yayınlanma 30.09 .2020

DOI: 10.29133 /yyutbd.702354

Anahtar kelimeler

Ot verimi,

Macar fiği,
Öz: Bu çalışmanın amacı, tritikale (x Triticosecale sp. Wittmack) ile Macar fiğinin (Vicia pannonica Crantz.) farklı tohum karışım oranlarının (HV, 75:25 HVT, 50:50HVT, 25:75 HVT ve T).) tritikalenin çiçeklenme dönemindeki ot verimi ve kalitesi ile rumende parçalanabilirlik özelliklerine etkisini belirlemekti. Araştırma, 2015-2016 vejatasyon döneminde Gaziosmanpaşa Üniversitesi Tarımsal Uygulama ve Araştırma Merkezi deneme sahalarında gerçekleştirilmiştir. Deneme tesadüf blokları deneme deseninde 3 tekrarlamalı olarak yürütülmüştür. Ayrıca, saf ve karışım kuru otların rumende kuru madde parçalanabilirlik özelliklerini belirlemek amacıyla rumenlerine kanül takılmış üç baş Karayaka koçu (50 kg canlı ağırlık ve ortalama 3 yaşında) kullanılmıştır. 
Yem değeri,

Rumende parçalanabilirlik, Tiritikale.
Yeşil ot ve kuru madde veriminin gruplar arasında farklı olmadığı, en yüksek ham protein konsantrasyonu (\% 13.12) ise saf ekili Macar fiğinde olduğu belirlenmiştir. $(\mathrm{P}<0.01)$. Ayrıca, maksimum ham protein verimi $75: 25 \mathrm{HVT}$ karışım grubundan elde edilmiş̧ir. Etkin kuru madde sindirilebilirliği (ED2, ED5 ve ED8) açısından, en yüksek kuru madde parçalanabilirliğine 50: 50HVT karışım grubunda (720.82, 706.1 ve $692.64 \mathrm{~g} / \mathrm{kg}$ ) bulunmuştur. Sonuç olarak, Macar fiğ ve tritikale karışık ekim durumunda, saf ekime göre daha fazla sindirilebilir kuru madde verimi ve ham protein veriminin elde edilebileceği sonucuna varılmıştır.

\section{Introduction}

The Hungarian vetch (Vicia pannonica) is an annual and cool season legume plant that can survive freezing without any damage. It is generally recommended for arid regions, with delicious leaf, forage and crude protein yield (CP) is high (Tuna and Orak, 2007). Due to the weak body of the Hungarian vetch, it easily lies in the growing period and is very difficult to harvest. There are rotting in the lower parts of the plant. For this reason, it is recommended to be mixed with grains and planted. When the vetches are planted mixed with cereals, they grow upright by wrapping them in cereal crops. With mixed cultivation, harvesting becomes easier (Kusvuran et al., 2014). It has been reported by the researchers that the most suitable form of time in the plantings mixed with the wheat crops is $30-36 \%$ of the dry matter of the plant mixtures or in the milk stage of wheat (Aksoy and Nursoy, 2010). On the other hand, triticale plant is a hybrid of wheat and rye and has been obtained as a result of long-term improvement studies in many countries. Triticale plants as forage are a great source of energy for ruminant animals (Avellaneda et al., 2009). It is stated that cultivation of triticale together with legumes may increase roughage quality and product amount according to growing triticale alone (Karadag and Buyukburc, 2003). The quality of legume-wheat mixtures as roughage varies depending on seed rates. In this context, Lithourgidis et al. (2006) stated that the common vetch: triticale seed rates were sown as 55:45 and 65:35, Green feed production and crude protein level were fond 10.3 ton ha ${ }^{-1}$ and $10.9 \%$ respectively. Also, NDF levels were determined to be 40.3 and $45.6 \%$. One of the most important differences between the cereals and legumes is cell wall digestibility of plant fragmentation. Legumes leaves have a faster cell wall digestion rate than cereals. Because higher rates of non-lignified tissues are higher than those of cereals (Paulson et al., 2008). In addition, since there are less lignified tissues in legume leaves, the rate of cell wall digestion is faster than that of cereals. However, the digestibility of wheat grain is higher than that of legumes (Paulson et al., 2008). Although the digestibility of wheat plants has increased for a long time in the rumen, the lignified xylem leguminous walls show minimal digestion over long periods of time (Jung, 2012). Obviously, the complexity of the legume cell wall, how it affects digestion, remains unclear. The objective of this study was to examine in terms of hay production and nutritive value of different seed rates of triticale-Hungarian vetch grown under the Central Black Sea region area in Tokat.

\section{Materials and Methods}

This study was carried out in accordance with the permission of the Local Ethics Committee of the Animal Experiments on 03.08.2015 dated 51879863-113 (HADYEK-38).

\subsection{Climate and soil characteristics of the research area}

A field experiment was carried out in Tokat Gaziosmanpaşa University Agricultural Research Center application area during 2015-2016 vegetation period.

Soil of trial area clayey, fertile and soil salt (2S / cm), pH, lime (\%), $\mathrm{P}_{2} \mathrm{O}_{5}(\mathrm{~kg} / \mathrm{ha}) \mathrm{K}_{2} \mathrm{O}$ (kg/ha) Organic matter (\%) were respectively $0.032,7.47,2.42$ 2.04, 1523.2, 19.8. The data related to the climate characteristics of the trial area are given in (Table 1).

In the study, Aegean white Hungarian vetch (HV) (Vicia pannonica Crantz.) variety and Tatlicak- 97 Triticale (T) (x Triticosecale sp. Wittmack) variety were used as plant material. The field experiment was designed in a Randomized Complete Block Design with three replications. Seeds of 
plant species pure $80 \mathrm{~kg} \mathrm{ha}^{-1}$ Aegean white (Hungarian vetch) and $250 \mathrm{~kg} \mathrm{ha}^{-1}$ Tatlicak-97 varieties were planted in the last week of October 2015. Experimental groups were sown as pure Hungarian vetch, triticale, $75 \%$ Hungarian vetch+25\% triticale, 50\% Hungarian vetch $+50 \%$ triticale and 25\% Hungarian vetch $+75 \%$ triticale mixtures. The seeds of triticale, Hungarian vetch and their mixture were sown with 15 markers and $20 \mathrm{~cm}$ row spacing. Each plot was $3 \mathrm{~m} \times 6 \mathrm{~m}\left(18 \mathrm{~m}^{2}\right)$ and the net research area was 17x23m: $391 \mathrm{~m}^{2}$. Pure and mixed plants were harvested during the flowering period of triticale. At harvest, plants were left as 2 rows from the edge of each plot and $0.5 \mathrm{~m}$ from the plot heads as a side effect and harvested in a net $2.6 \times 5=13 \mathrm{~m}^{2}$ area in each plot. Also weed control was done by hand.

Table 1. Climatic characteristics of trial area

\begin{tabular}{lccccccccc}
\hline \multicolumn{1}{c}{ Items } & March & April & May & June & July & August & Sept. & October & Total \\
\hline Precipitation $(\mathrm{mm})$ & 59.0 & 34.5 & 34.8 & 35.4 & 0.2 & 7.6 & 0.2 & 55.6 & 227.3 \\
Long years mean $(\mathrm{mm})$ & 57.1 & 23.6 & 31.9 & 48.5 & 3.8 & 4.4 & 19.6 & 51.8 & 240.7 \\
Average Temp $\left({ }^{0} \mathrm{C}\right)$ & 8.1 & 10.0 & 16.9 & 20.0 & 23.5 & 24.3 & 23.2 & 16.1 & 17.8 \\
Long years mean $\left({ }^{0} \mathrm{C}\right)$ & 9.7 & 13.5 & 18.0 & 21.0 & 24.8 & 25.6 & 22.5 & 15.7 & 18.9 \\
\hline Sept.: September. & & & & & & & & &
\end{tabular}

\subsection{Chemical analysis}

The trial plants were harvested as 3 replicates and dried at $70{ }^{\circ} \mathrm{C}$ for 48 hours to determine the dry matter (DM) contents. For the chemical analysis of the feed samples milled and passed through a 1 $\mathrm{mm}$ sieve. The ash content of the forage samples were found in the muffle furnace at $525^{\circ} \mathrm{C}$ for 8 hours. Crude protein content of forage samples was determined by multiplying the total nitrogen amount determined by Kjeldahl method with 6.25 coefficient (AOAC, 2012). Also, NDF and ADF contents of the feed samples were determined by Ankom (Ankom 200 Fiber Analyzer. Ankom tech.) (Van Soest et al., 1991).

\subsection{Calculation} below.

Net energy lactation (NEL) values of dry herbage samples were calculated by the formulas given

$$
\begin{gathered}
\mathrm{NEL}, \mathrm{Mcal} / \mathrm{kg}=2.0575-(0.0199 * \mathrm{ADF}) \text { (legumes) } \\
\mathrm{NEL}, \mathrm{Mcal} / \mathrm{kg}=2.149-(0.0223 * \mathrm{ADF}) \text { (legume and grass mixture) } \\
\mathrm{NEL}, \mathrm{Mcal} / \mathrm{kg}=2.296-(0.0257 * \mathrm{ADF}) \text { (grass) }
\end{gathered}
$$

Equations were used (NRC, 2007).

Digestible dry matter (DDM) of forages were calculated by using this equation

$$
\text { DDM=88.9-(0.779*ADF \%), }
$$

Dry matter intake potential (as percent of body weight) (PDMI) was determined by using this equation,

Specified by Jaranyama and Garcia (2004).

$$
\mathrm{PDMI}=120 /(\mathrm{NDF} \%)
$$

\subsection{In situ incubations}

DM, OM and NDF degradabilities and degradation characteristics of feed samples were determined by in situ method. Three Karakaya rams ( $50 \pm 0.3 \mathrm{~kg}$ live weight, 3 years old) fitted with a ruminal cannula (3.5 cm inner diameter, Diamond Inc.) were employed for the rumen degradability study. Rams were placed into individual compartments three weeks before the trial start to adapt the trial conditions. Rams were fed with a mixture of $70 \%$ alfalfa hay and $30 \%$ grass (8.00 in the morning 
and 16.30 in the evening) also minerals and salt. During the trial, fresh and clean water were kept in front of them. Forage samples of trial were ground at a length of $2.5 \mathrm{~mm}$, and $5 \mathrm{~g}$ was placed in bags which made of polyester with a pore diameter of 40-50 microns. Digestibility experiment was carried out a completely randomised design with rams as block. Feed samples were put in to the rumen as three replicates for incubations and incubated at $0,24,48,96$ hours in the rumen. Ruminal degradability (D) of nutrients (DM, OM and NDF) were calculated by the formula given below.

$$
\mathrm{D}=\frac{\text { (Initial sample weight (g) - (weight of sample at end of incubation (g))/ }}{\text { (Initial sample weight (g)) } \times 100)}
$$

Degradation characteristics of nutrients (DM, OM and NDF) were calculated by Ørskov and McDonald (1979) and Van Soest et al (1991) using the equation,

$$
\mathrm{D}=\mathrm{a}+\mathrm{b}\left(1-\mathrm{e}^{-\mathrm{ct}}\right)
$$

Where; D: disappearance rate of nutrients at time $t$. a: the portion of nutrients (DM, OM) solubilized at the beginning of incubation (time 0 ). $\mathrm{b}=$ slowly degraded nutrients (DM, OM and NDF) in the rumen c: rate constant of disappearance of ' $b$ ', $t=$ time of incubation, $e=$ the natural logarithm of a number. Degradation characteristics; a, b, c and effective ruminal degradability of DM, OM and NDF were calculated by Van Soest et al (1991). The effective DM and OM degradability were calculated by using equation,

$$
\mathrm{ED}_{(\mathrm{DM} \text { and } \mathrm{OM})}=\mathrm{a}+(\mathrm{bc} / \mathrm{c}+\mathrm{k})
$$

In addition, the effective NDF degradability were calculated by using this equation,

$$
\mathrm{ED}_{(\mathrm{NDF})}=\mathrm{b}+(\mathrm{bc} / \mathrm{c}+\mathrm{k})
$$

Where: $\mathrm{k}=$ ruminial out flow rate, $\mathrm{k}_{1}=0.02 / \mathrm{h}, \mathrm{k}_{2}=0.05 / \mathrm{h}$ and $\mathrm{k}_{3}=0.08 / \mathrm{h}$, for DM, OM and NDF.

\subsection{Statistical analysis}

Statistical analysis was performed using the GLM procedure of SPSS Software-16 for Windows (SPSS, 2007). As a mathematical model for the effect of pure and mixture groups;

$$
\text { Yijk }=\mu+a i+e i j k
$$

This equality, Yijk: Observation value, $\mu$ : General average, ai: Effect of research groups ( $\mathrm{i}=$ $1,2,3,4,5)$, eijk: Used as error value. "Tukey" multiple comparison test was used to determine the difference between research groups. SPSS (2013) package program was used for all operations.

\section{Results}

\subsection{Biomass yield and dry matter content}

Hungarian vetch had the lowest dry matter in the other groups (Table 2). Dry matter increased with increasing triticale ratio in mixtures. The difference between the Hungarian vetch and other groups of dry matter was also statistically significant $(\mathrm{P}<0.001)$.

\subsection{Chemical content of forages}

Crude protein concentration was highest in monoculture sown HV and 75:25 HVT mixture in the experimental groups, while the lowest crude protein content was obtained from the pure sowing 
triticale (Table 2). Differences in crude protein content were significant among the experimental groups $(\mathrm{P}<0.01)$.

It was determined that there was no statistical difference between the experimental groups in terms of ash concantrations. Although, there was no difference among the research groups, the highest ash content was obtained from 25:75 HVT group and at least 75:25 HVT mixture group.

Table 2. Forage yield and chemical composition of pure species and mixtures

\begin{tabular}{lcccccccc}
\hline \multirow{2}{*}{ Items } & \multicolumn{7}{c}{ Research } & groups \\
Seed rates (\%) & HV & HV: T & HV:T & HV:T & T & Mean & SEM & P value \\
\hline Nutrients $\left(\mathrm{g} \mathrm{kg}^{-1}\right)$ & & $75: 25$ & $50: 50$ & $25: 75$ & 100 & & & \\
DM & $262.3^{\mathrm{b}}$ & $335.1^{\mathrm{a}}$ & $336.1^{\mathrm{a}}$ & $340.6^{\mathrm{a}}$ & $340.3^{\mathrm{a}}$ & 322.9 & 0.88 & $<0.00^{* * *}$ \\
CP & $131.2^{\mathrm{a}}$ & $111.3^{\mathrm{a}}$ & $100.9^{\mathrm{ab}}$ & $90.9^{\mathrm{ab}}$ & $52.5^{\mathrm{b}}$ & 97.3 & 0.80 & $0.004^{* *}$ \\
Hemicellulose & 161.5 & 157.1 & 127.2 & 168.5 & 155.9 & 154.0 & 0.80 & 0.598 \\
ADF & 291.9 & 297.6 & 291.7 & 287.9 & 317.1 & 297.2 & 0.40 & 0.119 \\
NDF & 453.4 & 454.7 & 418.8 & 456.3 & 473.0 & 451.3 & 0.83 & 0.413 \\
Ash & 75.2 & 68.9 & 74.2 & 93.5 & 65.3 & 75.4 & 0.37 & 0.121 \\
\hline Production $\left(\mathrm{kg} \mathrm{ha}^{-1}\right)$ & & & & & & & & \\
Biomass & 16.757 & 22.167 & 17.820 & 18.845 & 16.323 & 18.382 & 106.1 & 0.474 \\
C PY & $575.1^{\mathrm{ab}}$ & $832.4^{\mathrm{a}}$ & $603.2^{\mathrm{ab}}$ & $554.3^{\mathrm{ab}}$ & $292.2^{\mathrm{b}}$ & 571.4 & 5.63 & $0.018^{*}$ \\
\hline
\end{tabular}

HV: Hungarian vetch, T:Triticale, DM: dry matter, CP: crude protein , ADF: acid detergent fiber, CPY: crude protein yield, SEM: standard error mean, $* \mathrm{P}<0.05,{ }^{* *} \mathrm{P}<0.01,{ }^{* * *} \mathrm{P}<0.001$

Crude protein yield was significantly influenced by mixture, the highest crude protein yield was obtained from 75:25 HV:T group followed by pure Hungarian vetch and other mixture groups (Table 2). The lowest protein yield was found to be as pure sown triticale group. Differences between the groups were found to be statistically significant $(\mathrm{P}<0.05)$.

Table 3. Nutritive values of pure species and mixtures

\begin{tabular}{|c|c|c|c|c|c|c|c|c|}
\hline \multirow[t]{2}{*}{ Items } & \multicolumn{8}{|c|}{ Research groups } \\
\hline & $\mathrm{HV}$ & HV: T & $\mathrm{HV}: \mathrm{T}$ & $\mathrm{HV}: \mathrm{T}$ & $\mathrm{T}$ & Mean & SEM & $\mathrm{P}$ value \\
\hline Seed rates $(\%)$ & 100 & $75: 25$ & $50: 50$ & $25: 75$ & 100 & & & \\
\hline DDM $\left(\mathrm{g} \mathrm{kg}^{-1}\right)$ & 661.6 & 642.0 & 657.2 & 661.0 & 664.8 & 657.5 & 0.31 & 0.118 \\
\hline DDMY (kg ha-1) & 2907.6 & 3550.1 & 4882.8 & 3937.8 & 4222.9 & 3900.2 & 25.09 & 0.084 \\
\hline PDMI (kg \% BW-1) & 2.66 & 2.87 & 2.64 & 2.63 & 2.63 & 2.67 & 0.049 & 0.188 \\
\hline $\mathrm{NE}_{\mathrm{L}}\left(\mathrm{M} . \mathrm{cal} \mathrm{kg}{ }^{-1}\right)$ & 1.48 & 1.48 & 1.51 & 1.49 & 1.50 & 1.49 & 0.007 & 0.718 \\
\hline
\end{tabular}

HV: Hungarian vetch, T: Triticale, DDM: digestible dry matter, DDMY: Digestible dry matter yield, PDMI: potential dry matter intake, $\mathrm{NE}_{\mathrm{L}}$ : net energy lactation, SEM: Standard error mean

The highest digestible dry matter value was taken from the HV group, followed by 25:75 HV+T group and the lowest value was in the 75:25 HVT group (Table 3). Although there was no significant difference between the experimental groups in terms of digestible dry matter

Dry matter intake, expressed as a percentage of the body weight of the animals. Although there was no statistically significant difference among the groups in terms of dry matter intake (Table 3) the 75:25 HVT forage group observed the highest intake potential. Potential feed intake tended to decrease with increasing triticale levels in the mixtures. The average NEL was $1.49 \mathrm{Mcal} / \mathrm{kg}$ and there were no significant differences between the treatments in terms of NEL values. When the research groups were compared (Table 3).

It was observed that there was no statistical difference between the experimental groups in different incubation periods in terms of dry matter degradability in the rumen (Figure 1). 


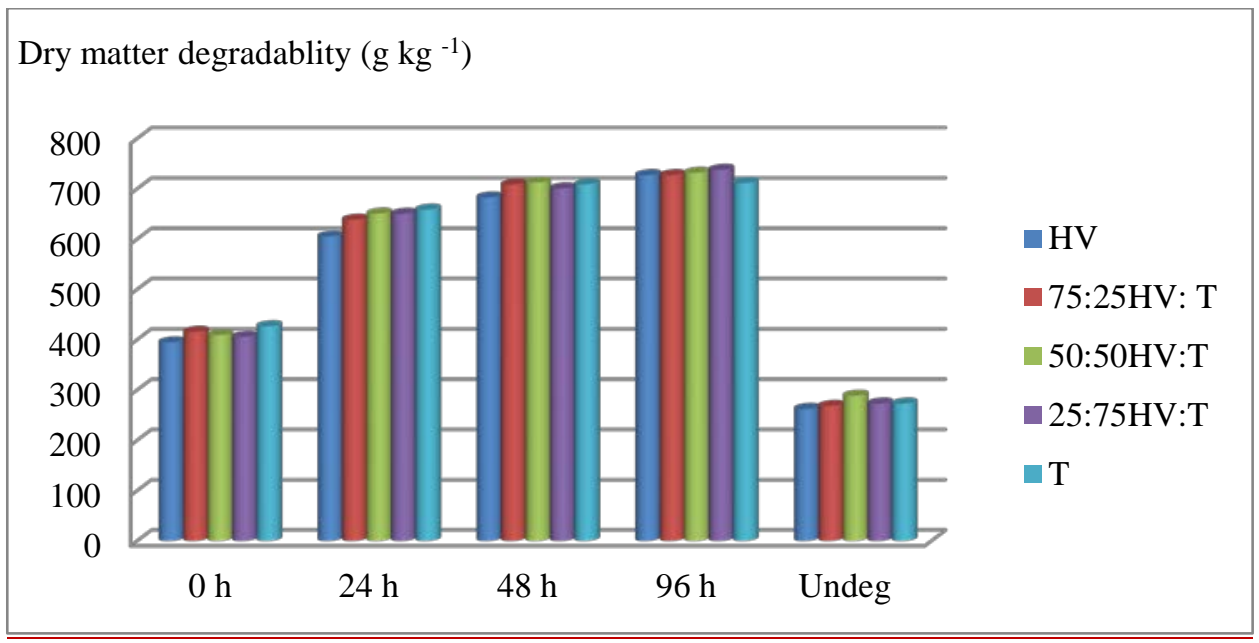

Figure 1. Dry matter degradability of pure and mixed forages in different rumen incubations.

Rumen degradation characteristics as rapidly soluble fraction (a), non- soluble but degradable fraction (b), potential degradable fraction $(\mathrm{a}+\mathrm{b})$, degradation rate (c) and rumen out flown rate of pure and mixtures of Hungarian vetch and triticale hay as presented in (Table 4). Easily soluble fraction (a) of dry matter of triticale had the highest solubility value in the other groups. This was followed, 75:25 HVT, 50:50 HVT and 25:75 HVT mixtures groups respectively,. But it was found that least solubility of parameter (a) was HV group. It was observed that triticale had more easily soluble dry matter parameter (a) than Hungarian vetch.

Hungarian vetch was above the average value, while the lowest value was in the triticale group. Also, It was determined that there were not any differences among the experimental groups in terms of parameter (b), (a+b) and (c) of DM and OM. Dry matter of triticale had highest ruminial out flow rate (k) in the experimental groups. This was followed 25:75 HVT, 50:50 HVT and 75:25 HVT mixtures. Although, the lowest ruminial out flow rate $(\mathrm{k})$ was determined in the HV group, there was no statistical difference among the experimental groups.

However, the lowest effective dry matter digestibility was determined in the triticale group. The difference between experimental groups was not statistically significant in terms of effective dry matter degradability.

Additionally, it was determined that there was no statistical difference between the experimental groups in terms of degradation characteristics (a, b, a+b, c, ED2, ED5 and ED8) of organic matter.

Although the highest values were obtained from HV pure cultivated group in terms of rumen organic matter degradability characteristics (b, a+b, c, ED2, ED5 and ED8), there were no statistically significant difference between the experimental groups (Table 4).

The degradable fraction b of NDF varied between 448.6 and $707.5 \mathrm{~g} \mathrm{~kg}^{-1}$ (Table 4). The difference between experimental groups was statistically significant in terms of degradable fraction (b) $(\mathrm{P}<0.05)$. Also, degradation rate (c) of NDF of 25HV:75T was highest value of in the experimental groups $(\mathrm{P}<0.001)$.

Effective NDF degradability of 25:75 HVT group in both rumen transition rate $(\mathrm{k}=0.05, \mathrm{k}=0.08)$ had the highest value in the experimental groups. There was significant difference among the groups $(\mathrm{P}<0.05)$. Also, it was found that there was no difference between the trial groups in terms of undegradable NDF. 
Table 4. Dry matter, NDF and OM degradation characteristics of pure and mixture forages

\begin{tabular}{|c|c|c|c|c|c|c|c|c|}
\hline \multirow{3}{*}{$\begin{array}{l}\text { Items } \\
\text { Seed rates (\%) }\end{array}$} & \multicolumn{6}{|c|}{ Research groups } & \multirow{3}{*}{ SEM } & \multirow{3}{*}{$P$ value } \\
\hline & $\mathrm{HV}$ & HV: T & HV:T & HV:T & $\mathrm{T}$ & Mean & & \\
\hline & 100 & $75: 25$ & $50: 50$ & $25: 75$ & 100 & & & \\
\hline \multicolumn{9}{|l|}{$\mathrm{DM}\left(\mathrm{g} \mathrm{kg}^{-1}\right)$} \\
\hline a & 394.50 & 415.7 & 409.0 & 405.67 & 426.7 & 410.31 & 6.15 & 0.616 \\
\hline $\mathrm{b}$ & 332.53 & 311.33 & 322.7 & 318.40 & 284.8 & 313.95 & 13.84 & 0.891 \\
\hline$a+b$ & 727.03 & 727.03 & 731.7 & 737.67 & 711.5 & 726.97 & 16.17 & 0.994 \\
\hline $\mathrm{c}\left(\mathrm{h}^{-1}\right)$ & 0.064 & 0.058 & 0.060 & 0.062 & 0.053 & 0.059 & 0.00019 & 0.387 \\
\hline$k\left(0.02 h^{-1}\right)$ & 0.0687 & 0.0693 & 0.069 & 0.069 & 0.071 & 0.069 & 0,000017 & 0.994 \\
\hline ED2 & 716.3 & 715.96 & 720.8 & 713.85 & 700.08 & 713.40 & 17.23 & 0.998 \\
\hline ED5 & 701.7 & 701.0 & 706.1 & 699.9 & 684.86 & 698.71 & 16.90 & 0.998 \\
\hline ED8 & 688.3 & 687.4 & 692.6 & 687.16 & 671.27 & 685.36 & 16.57 & 0.997 \\
\hline Undeg & 272.97 & 272.97 & 268.33 & 262.33 & 288.53 & 273.03 & 16.16 & 0.994 \\
\hline \multicolumn{9}{|l|}{ NDF $\left(\mathrm{g} \mathrm{kg}^{-1}\right)$} \\
\hline$b$ & $448.6^{c}$ & $593.5^{b}$ & $706.0^{\mathrm{a}}$ & $707.5^{\mathrm{a}}$ & $698.5^{a b}$ & 630.8 & 34.346 & $0.035^{*}$ \\
\hline$c\left(h^{-1}\right)$ & $0.014^{b}$ & $0.018^{b}$ & $0.040^{\mathrm{a}}$ & $0.041^{\mathrm{a}}$ & $0.039^{\mathrm{a}}$ & 0.030 & 0.003 & $0.000^{* * *}$ \\
\hline ED5 & $432.0^{b}$ & $576.4^{\mathrm{ab}}$ & $697.1^{a b}$ & $698.8^{a}$ & $689.2^{\mathrm{ab}}$ & 618.7 & 34.939 & $0.027 *$ \\
\hline ED8 & $422.7^{b}$ & $566.7 \mathrm{ab}$ & $691.7^{\mathrm{a}}$ & $693.6^{\mathrm{a}}$ & $683.6^{a}$ & 611.7 & 35.249 & $0.024 *$ \\
\hline Undeg & 384.43 & 268.53 & 278.07 & 278.30 & 284.30 & 298.73 & 24.21 & 0.59 \\
\hline \multicolumn{9}{|l|}{$\mathrm{OM}\left(\mathrm{g} \mathrm{kg}^{-1}\right)$} \\
\hline a & 429.70 & 456.77 & 446.87 & 442.57 & 447.33 & 444.65 & 6.44 & 0.815 \\
\hline $\mathrm{b}$ & 387.70 & 305.70 & 348.90 & 346.73 & 366.07 & 351.02 & 16.12 & 0.653 \\
\hline$a+b$ & 817.37 & 762.47 & 795.77 & 789.3 & 813.40 & 795.66 & 19.93 & 0.940 \\
\hline $\mathrm{c}\left(\mathrm{h}^{-1}\right)$ & 0.0067 & 0.0053 & 0.0060 & 0.0060 & 0.0062 & 0.0060 & 0.0002 & 0.271 \\
\hline ED5 & 789.35 & 733.97 & 766.62 & 761.80 & 785.59 & 767.47 & 19.39 & 0.936 \\
\hline ED8 & 774.42 & 719.40 & 751.45 & 747.38 & 770.89 & 752.71 & 19.23 & 0.932 \\
\hline
\end{tabular}

HV: Hungarian vetch, T:Triticale, SEM: standard error mean, ${ }^{*} \mathrm{P}<0.05,{ }^{*} \mathrm{P}<0.01,{ }^{* * *} \mathrm{P}<0.001$.

\section{Discussion and Conclusion}

Triticale -Hungarian vetch mixtures did not lead to a significant change in biomass yield. However, green herbage production of 75:25 HV + T group; 24\% more than Hungarian vetch and 26\% more than Triticale. Biomass yields of mixtures were higher than pure sowing yields. Similar results have been reported in Hungarian vetch triticale intercropping by Yıldırım and Özarslan Parlak (2016). Also, Lithourgidis et al. (2006) reported that forage yield was not affected by the increase of common vetch ratio in the mixtures. However, our triticale green herbage yield findings were lower than the values indicated by Karabulut and Çaçan (2018). This difference was thought to be caused by the ecology of the region and the difference in the used varieties.

The dry matter of the Hungarian vetch during the harvest period was found to be lower in both triticale and herbage obtained from mixed cultivation. Dry matter of forage increased with increasing triticale seed rate. Similar findings have been reported by Roberts et al. (1989) that DM decreased with increasing common vetch ratios in mixture with wheat.

Crude protein concentration of forage is one of the most important criteria for forage quality (Assefa and Ledin, 2001). The crude protein content of herbage of pure seeding Hungarian vetch was the highest $(131.2 \mathrm{~g} / \mathrm{kg}$ ) among all herbages obtained from other mixtures. Pure triticale seeding produced herbage with the lowest crude protein content $(52.5 \mathrm{~g} / \mathrm{kg})$. When the ratio of common vetch in any mixture increased, so did the crude protein content of that mixture also. Generally, the protein levels of legumes are higher than that of cereals. Also, In the sowing of the mixture, the crude protein content of the mixtures decreased as the ratio of legume seed in the mixtures decreased. These results were in agreement with those reported by Kokten et al. (2009); Yücel and Avc1 (2009); Y1ldırım and Parlak (2016) that crude protein concentration of monoculture vetch and containing $60 \%$ vetch and $40 \%$ triticale group were higher than the other mixtures and pure sown triticale group. Also, the findings, under different locations of Lithourgidis et al. (2006) and Budaklı Çarpıcı and Çelik (2014) supported our results. However, average crude protein concentration of pure and mixtures sowing less than reflected by Karadağ and Büyükburç (2003); Yücel and Avc1 (2009); Yılmaz et al. (2015); Karabulut and Çaçan (2018).

In this study, the NDF and ADF contents of the HV were lower than the triticale and HV+T mixtures. NDF and ADF content of the herbage obtained due to the increase of triticale seed rate in 
mixed plantings also increased. NDF and ADF content in feeds is an important quality criterion. (Assefa and Ledin, 2001). Similar findings reflected by Lithourgidis et al. (2006) and Y1ldrrm et al. (2016).

Crude protein production from the 75:25 HVT mixture group; It was 31\% higher than the HV group and 65\% more than the triticale group. In general, mixture groups produced more crude protein than pure cultivation. When the groups were compared. This could be explained by the fact that the land use efficiency in 75:25HVT group in Tokat conditions was better than HV, triticale and other mixing ratios. This results in agreement reported findings by Kökten et al. (2009); Budaklı Çarpıcı et al. (2014) and Doğrusöz et al. (2019). But these results were lower than those reflected by Karadağ and Büyükburç (2003). It was thought that the differences between the protein yields might be due to the differences in variety and environmental conditions

Digestible dry matter is a function of ADF and there is a negative correlation between them. In this study, the ADF content of Hungarian vetch was lower than triticale. Similar results reflected by Y1lmaz et al. (2015).

The digestible dry matter yield of the 50:50 mixture group was higher than the other experimental groups, followed by triticale and other mixture groups and the lowest production was obtained from the Hungarian vetch group. This results were in agreement with those reported by Yucel and Avc1 (2009). Similar results have been reported by Altın and Ucan (1996); Tuna and Orak (2007).

Potential feed intake tended to decrease with increasing triticale levels in the mixtures. NDF was used to estimate DMI. There was a negative correlation between NDF and DMI. In other words, when NDF is high, both quality and potential DMI were low (Horrocks and Vallentine, 1999). Similar results reflected by Y1lmaz et al. (2015). But, Kaplan et al. (2015) reported that the results obtained from the study investigating the potential feed intake of different triticale varieties (Tatlicak) were lower than our results. This was thought to be caused by different agronomic and environmental conditions.

Although the 50: $50 \mathrm{HVT}$ group had slightly higher $\mathrm{NE}_{\mathrm{L}}$ than other groups, it was observed that there was no difference between the groups. Closer fibrous compounds of Hungarian vetch and triticale also resulted in insignificant differences in $\mathrm{NE}_{\mathrm{L}}$ values. Similarly, Lauriault and Kirksey (2004) found that pea mixtures with rye and barley had no effect on net energy. Also, Similar results for NEL values were also reported by Aksoy and Nursoy (2010) for the vetch- wheat mixture. Whereas, Sadeghpour et al. (2014) stated that there was a significant increase in NEL values with increasing legume ratio in mixtures.

Degradation kinetics of nutrients of feeds in rumen; It is thought to be important in terms of estimating the nutritional needs of animals. When the degradability data of nutrients in the rumen were examined in this respect; pure and different mixtures of Hungarian vetch and triticale; It was determined that it had no effect on some kinetics (a, b, a+b, c, $\mathrm{ED}_{\mathrm{DM}}$ and $\mathrm{ED}_{\mathrm{OM}}$ in the rumen. Similar findings for alfalfa and oats reported by Ximena Valderrama and René Anrique (2011). Also, Dewhurst et al. (2003) declered that there was no consistent difference between the legumes and grass in terms of degradation characteristics. But, Box et al. (2018), In their study with Hungarian vetch and triticale and their mixtures; they stated that the effective dry matter degradability (ED2, ED5 and ED8) of the 50:50 HVT mixture group was higher than the other groups.

In this study, when the experimental groups were compared in terms of the degradability characteristics of the cell walls. It was observed that the values of 50:50 and 25:50 mixture groups were higher than the other groups. NDF degradation kinetics increased with increasing triticale ratio in mixtures. Regarding mixtures, Zhang et al., (2015) reflected that a combination of legume and wheat; intercropping material in terms of NDF degradability have probably produced a positive binding effect. Also, Hoffman et al. (1993) stated that legumes had a low NDF content, but had a higher lignin content in NDF, whereas grass had a lower lignin content in NDF, but a higher ADF and NDF content. Besides, concentration and degradation characteristics of NDF were important factors determining the energetic value of forages for ruminants (Moharrery et al., 2009).

Some researchers have determined that legumes had a faster degradation compared to grasses, and the presence of legumes probably accelerates the degradation of grasses (Halmemies-BeauchetFilleau et al., 2013). Also, the association of legumes with grass may produce a synergistic effect with optimal energy-to protein ratio and improved effective degradability from increased microbial profiles due to multiple substances (Metzler Zebeli et al., 2012). On the other hand, the relational effects between grass and legumes can be attributed to bioactive ones. 
As a result, the biomass production and crude protein yield of the 75:25 HVT group were 21\% and $31 \%$ higher than the average of the experimental groups, respectively. Also, considering the effective dry matter digestibility of the experiment groups; Since the highest digestible dry matter production was found to be in the 75:25 HVT group, it was thought that the most suitable seed mixture for the cultivation of Hungarian vetch-triticale in Tokat conditions would be 75:25 HVT.

\section{Acknowledgements}

This work is part of the scientific research project (2015/121) financially supported by Gaziosmanpasa University. We express our sincerest gratitude to them for their support

\section{References}

Aksoy, İ \& Nursoy H. (2010). Determination of the varying of vegetation harvested hungarian vetch and wheat mixture on nutrient content, degradation kinetics, in vitro digestibility and relative feed value. Journal of Kafkas Üniv. Vet. Faculty, 16, 925-931.

Altın, M. \& Ucan, M. (1996 ). Kumkale kıraç koşullarında değişik fiğ + yulaf karışımlarının farkı azot dozlar"ndaki hasılat verimleri ile karşım yapıları. Türkiye 3. Çayır-Mer’a ve Yembitkileri Kongresi, Erzurum, p: 334-340.

Assefa, G \& Ledin, I. (2001). Effect of variety, soil type and fertilizer on the establishment, growth, forage yield, quality and voluntary intake by cattle of oats and vetches cultivated in pure stands and mixtures. Anim. Feed Sci. and Tech., 92, 95-111.

Avellaneda, I H, Pinos-Rodrigez, S. S. \& Gonzales, S. S. (2009). Effects of exogenous fibrolytic enzymes on ruminal fermentation and digestion of Guinea grass hay. Anim. Feed Sci. and Techn., 149,70-77.

AOAC. (2012). Official method of analysis. $15^{\text {th }}$ ed., Association of Official Analytical chemist, Washington, DC. USA.

Box, LA., Edwards, G.R. \& Bryant, R.H. (2018). In sacco digestion kinetics of plantain and ryegrasswhite clover harvested in the morning and afternoon. New Zealand Journal of Animal Science and Production, 78, 18-26.

Budaklı Carpıcı, E \& Çelik, N. (2014). Forage yield and quality of common vetch mixtures with tritıcale and annual ryegrass. Turkish J. Field Crops, 19(1), 66-69.

Dewhurst, R J, Evans, R.T., Scollan, N.D., Moorby, J.M., Merry, R. J. \& Wilkins, R. J. (2003). Comparison of grass and legume silages for milk production. 1. Production responses with different levels of concentrate. Journal of Dairy Sci., 86 (8), 2598-2611.

Doğrusöz, M.Ç., Mut, H., Başaran, Ü.\& Gülümser, E. (2019). Performance of legumes-turnip mixtures with different seed rates. Turkish Journal of Agriculture Food Science and Technology, 7(1), 81-86.

Halmemies-Beauchet-Filleau A, Vanhatalo, A., Toivonen, V., Heikkilä, T., Lee, M.R.F. \& Shingfield K .J. (2013). Effect of replacing grass silage with red clover silage on ruminal lipid metabolism in lactating cows fed diets containing a 60:40 forage-to-concentrate ratio. J. Dairy Sci., 96, 5882-5900.

Hoffman, P. C., Sievert, R.D., Shaver, R.D. ,Welch, D.A. \& Combs, D.K. (1993). In situ dry matter, protein and fiber degradation of perennial forages. Journal of dairy sci., 76 (9), 2632-2643.

Horrocks, R.D. \& Vallentine, J.F. (1999). Harvested Forages. Academic Press, London, UK.

Jaranyama, P. \& Garcia, A.D. (2004). Understanding relative feed value (RFV) and relative forage quality (RFQ). College of Agric. and Biological Sci., South Dakota State University, USA.

Jung, H.G. (2012). Forage digestibility: the intersection of cell wall lignification and plant tissue anatomy. In: Proceedings of 23rd Ruminant Nutrition Symposium in Florida, USA.

Kaplan, M., Y1lmaz, M.F. \& Kara, R. (2015). Variation in hay yield and quality of new triticale lines. Tarım Bilimleri Dergisi - Journal of Agricultural Sciences, 21, 50-60.

Karabulut, D. \& Çaçan, E. (2018). Farklı zamanlarda ekilen bazı tahıl türlerinin ot verimi ve kalitesi bakımından karşılaştırılması. Alınteri Journal of Agriculture Sciences, 33(2), 125-131.

Karadag, Y. \& Büyukburç, U. (2003). Effect of seed rates on forage production, seed yield and hay quality of annual legume-barley mixtures. Turkish J. Agri. and Forestry, 27, 169-174. 
Kokten, K., Toklu, F., Atis, I. \& Hatipoglu, R. (2009). Effects of seeding rate on forage yield and quality of vetch (Vicia sativa L.) triticale (Triticosecale Wittm.) mixtures under East Mediterranean rainfed conditions. African J. Biotech., 8, 5367-5372.

Kusvuran, A., Kaplan, M. \& Nazl1, R. I. (2014). Effects of mixture ratio and row spacing in Hungarian vetch (vicia pannonica crantz.) and annual ryegrass (lolium multiflorum lam.) intercropping system on yield and quality under semiarıd climate conditions. Turkish Journal of Field Crops, 19(1), 118-128.

Lauriault, L.M. \& Kirksey, R.E. (2004). Yield and nutritive value of irrigated winter cereal forage grasslegume intercrops in the southern high plain, USA. Agron. J., 96, 352-358.

Lithourgidis, A. S., Vasilakoglou, I. B., Dhima, K.V., Dordas, C.A. \& Yiakoulaki, M. D. (2006). Forage yield and quality of common vetch mixtures with oat and triticale in two seeding ratios. Field Crops Research, 99, 106-113.

Metzler Zebeli B.U, Scherr, C., Sallaku, E., Drochner, W.\& Zebeli, Q. (2012). Evaluation of associative effects of total mixed ration for dairy cattle using in vitro gas production and different rumen inocula. J. Sci. Food Agr., 92, 2479-2485.

Moharrery, A., Hvelplund, T. \& Weisbjerg, M.R. (2009). Effect of forage type, harvesting time and exogenous enzyme application on degradation characteristics measured using in vitro technique. Anim. Feed Sci. and Techn., 153, 178-192.

NRC (2007). Nutrient requirements of small ruminants: Sheep, goats, cervids, and new world camelids. National Academy Press, 384 p. http://www.nap.edu/catalog/11654/nutrient-requirements-ofsmall-ruminants-sheep-

Ørskov, E.R. \& McDonald, I. (1979). The estimation of protein degradability in the rumen from incubation measurements weighed according to rate of passage. Journal Agri. Sci. (Camb.), 92(2), 499-503.

Paulson, J., Jung, H., Raeth-Knight, M. \& Linn, J. (2008). Grass vs Legume Forages for Dairy Cattle. pp 1-15 in Proc. Minnesota Nutr. Conf., Saint Paul, MA, USA.

Roberts, C.A, Moore, K.J. \& Johnson, K.D. (1989). Forage quality and yieldnof wheat-common vetch at different stages of maturity and common vetch seeding rate. Agronomy Journal, 81, 57-60.

Sadeghpour, A. E., Jahanzad, A. S., Lithourgidis, M., Hashemi, A., Esmaeili, A. \& Hosseini, M. B. (2014). Forage yield and quality of barley-annual medic intercrops in semi-arid environments. Int. J. Plant Produc., 8, 77-89.

SPSS. (2013). IBM SPSS Statistics 22.0 for Windows. Armonk, NY

Tuna, C. \& Orak, A. (2007). The role of intercropping on yield potential of common vetch (Vicia sativa L.)/ oat (Avena sativa L.) cultivated in pure stand and mixtures. J. Agric. Biol. Sci., 2(2),14-19.

Ximena Valderrama L.I, \& René Anrique G. (2011). In situ rumen degradation kinetics of high protein forage crops in temperate climates. Chilean Journal of Agricultural Research, 71(4), 572-577.

Van Soest, P.J., Robertson, J.B. \& Lewis, B.A. (1991). Methods for dietary fiber, neutral detergent fiber and non-starch polysaccharides in relation to animal nutrition. Journal of Dairy Sci., 74, 35833597.

Yıldırım, S \& Özarslan Parlak, A. (2016). Forage yield, quality of triticale intercrops with faba bean, pea and vetch at varying seeding ratio. Journal Agri. Faculty, 4 (1), 77-83.

Yılmaz, Ş, Özel, A., Atak, M.\& Erayman, M. (2015). Effects of seeding rates on competition indices of barley and vetch intercropping systems in the Eastern Mediterranean. Turkish J Agri. and Foresty, 39, 135-143.

Yucel, C. \& Avci, M. (2009). Effect of different ratios of common vetch (Vicia sativa L.) -triticale (Triticosecale whit.) mixtures on forage yields and quality in Cukurova plain in Turkey. Bulg. J. Agri. Sci., 15, 323-332.

Zhang, J., Yin, B., Xie, Y., Li, J., Yang, Z. \& Zhang, G. (2015). Legume-Cereal intercropping improves forage yield, quality and degradability. Plos One, 10(12),1-14. 